\title{
Major Determinants of Height Development in Turner Syndrome (TS) Patients Treated With GH: Analysis of 987 Patients From KIGS
}

\author{
MICHAEL B. RANKE, ANDERS LINDBERG, ANGEL FERRÁNDEZ LONGÁS, FEYZA DARENDELILER, \\ KERSTIN ALBERTSSON-WIKLAND, DAVID DUNGER, WAYNE S. CUTFIELD, MAÏTHÉ TAUBER, PATRICK WILTON, \\ HARTMUT A. WOLLMANN, AND EDWARD O. REITER, on behalf of the KIGS International Board
}

Paediatric Endocrinology Section [M.B.R.], Children's Hospital, University of Tuebingen, D-72076 Tuebingen, Germany; Pfizer Inc. [A.L.], S-11287, Stockholm, Sweden; Department of Pediatrics [A.F.L.], University Children's Hospital "Miguel Servet", ESP-50009 Zaragoza, Spain; Department of Paediatrics [F.D.], Cocuk Klinigi, Istanbul Faculty of Medicine, 34390 Istanbul, Turkey; Department of Pediatrics [K.A.W.], Pediatric Growth Research Center, Queen Silvia Children's Hospital, Sahlgrenska Academy, Goteborg University, S-41685 Goteborg, Sweden; Department of Pediatrics [D.D.], University of Cambridge, Cambridge CB2 2QQ, United Kingdom; Department of Pediatrics [W.S.C.], University of Auckland, Auckland 92019, New Zealand; Service de Pédiatrie Endocrinologie [M.T.], Hospitalier Universitoire, F-31059 Toulouse, France; Pfizer Inc. [P.W., H.A.W.], NY; Baystate Medical Center Children's Hospital [E.O.R.], Tufts University of Medicine, Springfield, MA 01199

\begin{abstract}
Little is known about factors determining height outcome during GH treatment in Turner syndrome (TS). We investigated 987 TS children within the Kabi International Growth Study (KIGS) who had reached near adult height (NAH) after $>4$ y GH treatment (including $>1$ y before puberty). Through multiple regression analysis we developed a model for NAH and total gain. Our results were as follows (median): 1) At start, age $9.7 \mathrm{yrs,} \mathrm{height} \mathrm{(HT)}$ $118.0 \mathrm{~cm}(0.0$ TS SDS), projected adult height $146.1 \mathrm{~cm}, \mathrm{GH}$ dose $0.27 \mathrm{mg} / \mathrm{kg}$ wk; 2) NAH HT $151.0 \mathrm{~cm}$ (1.5 TS SDS); 3) Prepubertal gain $21.2 \mathrm{~cm}$ (1.6 TS SDS); 4) Pubertal gain $9.4 \mathrm{~cm}(0.0$ TS SDS). NAH correlated $\left(r^{2}=0.67\right)$ with (ranked) HT at GH start $(+), 1^{\text {st }}$ year responsiveness to $\mathrm{GH}(+), \mathrm{MPH}(+)$, age at puberty onset $(+)$, age at $\mathrm{GH}$ start $(-)$, and dose $(+)$. The same factors explained $\left(\mathrm{R}^{2}=\right.$ 0.90) the total HT gain. However, HT at GH start correlated negatively. Karyotype had no influence on outcome. Evidently, height at $\mathrm{GH}$ start (the taller, the better), age at GH start (the younger, the better), the responsiveness to GH (the higher, the better) and age at puberty (the later, the better) determine NAH. (Pediatr Res 61: 105-110, 2007)
\end{abstract}

$\mathrm{S}^{\mathrm{h}}$ hort stature is the most constant clinical feature found in patients with Turner syndrome (TS) (1). The height deficit in adult Turner patients is approximately $20 \mathrm{~cm}$ below the female average in corresponding populations (2). To date, there is no convincing evidence to support the view that the growth disorder in TS is associated with a disorder in the growth hormone - IGF (GH-IGF) axis but, instead, to haploinsufficiency of the SHOX gene (3); however, substantial evidence has accumulated over the past $20 \mathrm{y}$ to show that treatment with supra-physiologic doses of recombinant human GH (rhGH) during childhood can lead to a higher adult height (4). Recent investigations have also shown that the short- and

Received May 11, 1006; accepted July 27, 2006.

Correspondence: Michael B. Ranke, M.D., University Children's Hospital, Paediatric Endocrinology Section, Hoppe-Seyler-Strasse 1, D-72076 Tuebingen, Germany; e-mail: Michael.Ranke@med.uni-tuebingen.de

DOI: $10.1203 / 01 . p d r .0000250039 .42000 . c 9$ long-term growth responses to $\mathrm{GH}$ treatment correlate positively with the GH dose (5).

Even though GH, as a mode of treatment, has been proved to be safe $(6,7)$, it is not possible to completely rule out the risks which may arise due to long-term elevation of $\mathrm{GH}$ and IGF levels (8). In addition, the cost of GH treatment is also an important aspect that needs to be considered (9). Therefore, in aiming to achieve the normalization of height by applying the lowest required amount of GH during the shortest possible duration, it is imperative to further optimize and individualize GH treatment in TS. The Pfizer International Growth Database, known as KIGS (and founded as the Kabi International Growth Study), currently contains nearly 1,000 Turner patients who were treated up to the achievement of adult height; it thus served as a unique source of data for our analysis of factors affecting height outcomes. Our findings show that it is possible for GH to be applied more effectively and efficaciously in the treatment of short stature in Turner syndrome in the future.

\section{SUBJECTS AND METHODS}

Patients. The patients we studied had received rhGH (Genotropin, Pfizer Corporation) as part of the large pharmaco-epidemiologic survey known as KIGS. The KIGS database is an international registry developed with the main objective of documenting the long-term outcomes and safety of Somatonorm and Genotropin, both authentic rhGH products (Pfizer, Inc., New York). The KIGS survey is conducted in accordance with the recommendations adopted by the $18^{\text {th }}$ World Medical Assembly (Helsinki, Finland, in 1964) and their subsequent revisions. Each subject and/or his/her legal representative received adequate information, has the right to withdraw from the survey at any time, and must give written consent for his/her participation. In contrast, KIGS did not require informed consent from the subjects or their legal representatives in many countries during the first decade of its existence. Currently, informed consent is required and the anonymous use of the data complies with rigorous privacy guidelines.

Abbreviations: KIGS, Kabi International Growth Study; MPH, mid-parental height; NAH, near adult height; rhGH, recombinant human GH; TS, Turner syndrome 
Table 1. Distribution of karyotypes in KIGS patients with Turner syndrome, showing the group as a whole and the group which reached near adult height (NAH)

\begin{tabular}{lcc}
\hline \multicolumn{1}{c}{ Karyotype } & All $(n=5,651)$ & $\mathrm{NAH}(n=987)$ \\
\hline $45, \mathrm{X}$ & $50.1 \%$ & $53.2 \%$ \\
$46, \mathrm{X}, \mathrm{Xp}-$ & $1.2 \%$ & $0.1 \%$ \\
46,X,Xq- & $0.6 \%$ & $0.1 \%$ \\
46,X,iXq & $7.3 \%$ & $6.0 \%$ \\
$46, \mathrm{X}, \mathrm{Xr}$ & $0.2 \%$ & $<0.1 \%$ \\
45,X/46,XX & $11.1 \%$ & $7.7 \%$ \\
45,X/46,X,Xr & $4.3 \%$ & $3.4 \%$ \\
45,X/46,X,Xq & $10.8 \%$ & $10.1 \%$ \\
45,X/47XXX & $4.3 \%$ & $2.5 \%$ \\
Other 45X, mosaic & $9.3 \%$ & $15.7 \%$ \\
variant & & \\
45,X/46,XY & $0.8 \%$ & $<0.1 \%$ \\
\hline
\end{tabular}

Methods. By June 2, 2005, the number of Turner patients documented in the KIGS registry totaled 5,651 cases. The distribution of karyotypes is listed in Table 1. We analyzed patients who were in the prepubertal stage throughout the first year of GH treatment, who had been treated for more than four years and had been followed-up to near adult height (NAH). NAH was defined by the following criteria: age at final visit $>15$ y old; height velocity during the last year on $\mathrm{GH}<2.0 \mathrm{~cm} / \mathrm{y}$; analysis of individual growth curves showing evidence of an asymptotic proximity to final height. Only individuals who received doses equal to or greater than 5 injections of GH per week were considered for the analysis. GH doses were approximately constant during the course of treatment. The onset of puberty was taken to be the time when spontaneous breast development (Tanner stage B2) was first observed or the date at which estrogen replacement therapy was initiated. The time elapsed between the prepubertal status and the observed onset of puberty was less than 6 mo. The assessment of the qualitative and quantitative aspects of estrogen replacement was done by the treating physicians and is not one of the aims of this study. Additional treatment with oxandrolone was done in 23 patients at the time of GH treatment initiation, in 52 patients after one year on GH, in 79 patients at the onset of puberty and in 94 patients at NAH.

For consistency with similar analyses in the past (10), we used the height standards of Tanner et al. for normal children (11) which have been corrected for the absence of puberty (12), and the weight standards of Freeman et al. (13). The height references for Turner individuals established by Ranke $e t a l$. (14) were also applied. Projected adult height (PAH) was calculated according to Lyon et al. (15). Birth weight for gestational age was transformed into an SD score (SDS) based on the standards of Niklasson et al. (16). The MPH (mid-parental height) SD score was calculated as follows: (father's height SD score + mother's height SD score $) \div 1.61$ (17). Bone age determinations were done by the treating physician and calculated according to the method of Greulich and Pyle (18). To analyze the extent of the observed growth during the first year on $\mathrm{GH}$, the height velocity was predicted according to the KIGS model for Turner patients (10), following which the studentized residual was calculated (see Statistical analysis).
Analysis of factors influencing near adult height and height gain. A multiple regression analysis was done with the aim of studying the factors influencing the height outcome of GH treatment. The dependent variables chosen were height $(\mathrm{cm})$ or change in height $(\mathrm{cm})$ between the start of $\mathrm{GH}$ treatment and the achievement of NAH.

The following independent variables were tested: 1) Status at birth: weight SD score, length SD score, ponderal index; 2) Genetic background: mother's height SD score, father's height SD score, midparental height (MPH) SD score, and karyotype; 3) Treatment modality: GH dosage [per kg of body weight and per $\mathrm{kg}$ of ideal body weight (weight for height)], frequency of GH injections, and accumulated years of GH treatment; 4) Variables at the start of treatment: age, bone age, height SD score, weight SD score, height SD score minus MPH SD score, the peak GH concentration in serum during stimulation tests; and 5)Variables at puberty onset: age, bone age, height SD score, weight SD score, height SD score minus MPH SD score. SD scores were calculated as follows: $\mathrm{SD}$ score $=$ (patient's measured value minus mean value for ageand sex-matched normal subjects $) \div \mathrm{SD}$ of the value for age- and sexmatched normal subjects.

Statistical analysis. Wilcoxon rank tests were used for the comparison of data, median values, and $10^{\text {th }}-90^{\text {th }}$ centile ranges. The Spearman correlation coefficients are quoted, and $p$-values correspond to two-sided tests. For multivariate regression analysis, the procedure REG in the programme package SAS ${ }^{\text {TM }}$ Version 8 was used.

Differences between observed and predicted height velocities were expressed in terms of studentized residuals. The residual is calculated as the observed height velocity minus the predicted height velocity for each observation, and the studentized residual is the residual divided by its SE. The prediction model for the first year of GH treatment in Turner syndrome $(n=$ 686) as described in a previous publication (10) explains $46 \%$ of the variability of the height velocity with an error SD of $1.26 \mathrm{~cm}$ in the case of six parameters (in order of importance): 1) GH dose $(+) ; 2)$ age at GH therapy start (-);3) weight $(+) ; 4)$ supplementary oxandrolone therapy $(+) ; 5)$ height at GH start minus MPH (-); and 6) number of GH injections per week $(+)$.

\section{RESULTS}

Description of patients treated to near adult height. A total of 987 Turner patients reached near adult height. The relative frequency of the documented karyotypes is listed in Table 1. This distribution of karyotypes was not significantly different from the total group of 5,651 TS patients in KIGS. The characteristics of patients before GH therapy start and at the time of GH start are listed in Table 2. The characteristics of the subjects after one year of GH and at the onset of puberty are listed in Table 3 . The characteristics of patients at the time near adult height was reached are listed in Table 4.

Birth weight at a median gestational age of $40 \mathrm{wk}$ was 1.0 SDS below the population mean $(p<0.001)$ while midparental height (MPH, 0.1 SDS) was not different. Age at the

Table 2. Characteristics of patients before GH therapy and at GH therapy start

\begin{tabular}{|c|c|c|c|c|c|c|}
\hline Variables & $n$ & Median & $10^{\text {th }}$ centile & $90^{\text {th }}$ centile & Mean & SD \\
\hline \multicolumn{7}{|l|}{ Background } \\
\hline Gestational age (weeks) & 928 & 40.0 & 36.0 & 41.0 & 38.9 & 1.9 \\
\hline Birth weight (SDS) & 917 & -1.0 & -2.6 & 0.4 & -1.1 & 1.2 \\
\hline $\operatorname{maxGH}$ to tests $(\mathrm{g} / \mathrm{L})$ & 637 & 12.1 & 4.7 & 28.1 & 14.3 & 9.4 \\
\hline \multicolumn{7}{|l|}{ GH therapy } \\
\hline Age (years) & 987 & 9.7 & 5.8 & 12.3 & 9.3 & 2.4 \\
\hline Height velocity $(\mathrm{cm} / \mathrm{yrs})$ & 408 & 4.3 & 2.7 & 6.0 & 4.4 & 1.4 \\
\hline Height (Tanner) (SDS) & 987 & -2.4 & -3.4 & -1.5 & -2.6 & 0.8 \\
\hline Height TS (Ranke) (SDS) & 987 & 0.0 & -1.3 & 1.1 & -0.1 & 1.0 \\
\hline Projected adult height (SDS) & 987 & 146.1 & 138.2 & 153.1 & 145.9 & 5.9 \\
\hline BMI (SDS) & 987 & 0.2 & -1.1 & 1.6 & 0.2 & 1.0 \\
\hline GH dose (mg/kg wk) & 987 & 0.27 & 0.17 & 0.37 & 0.27 & 0.08 \\
\hline
\end{tabular}


Table 3. Characteristics of patients after one year of GH and at onset of puberty

\begin{tabular}{|c|c|c|c|c|c|c|}
\hline Variables & $n$ & Median & $10^{\text {th }}$ centile & $90^{\text {th }}$ centile & Mean & SD \\
\hline \multicolumn{7}{|l|}{ After one year on GH } \\
\hline Age (years) & 904 & 10.7 & 6.8 & 13.2 & 10.3 & 2.4 \\
\hline Bone age (years) & 471 & 10.0 & 6.8 & 11.5 & 9.3 & 2.1 \\
\hline Height (Tanner) (SDS) & 904 & -1.9 & -3.0 & -0.9 & -2.3 & 1.0 \\
\hline Height TS (Ranke) (SDS) & 904 & 0.7 & -0.7 & 2.0 & 0.6 & 1.0 \\
\hline BMI (SDS) & 898 & 0.1 & -1.1 & 1.4 & 0.1 & 1.0 \\
\hline Studentized residual (SDS) & 752 & 0.0 & -1.4 & 1.3 & 0.0 & 1.1 \\
\hline Delta height (Tanner) (SDS) & 904 & 0.5 & 0.2 & 0.8 & 0.3 & 0.3 \\
\hline Delta height (Ranke) (SDS) & 904 & 0.7 & 0.3 & 1.1 & 0.7 & 0.3 \\
\hline \multicolumn{7}{|l|}{ Puberty onset } \\
\hline Age (years) & 540 & 13.5 & 11.6 & 15.7 & 13.6 & 1.6 \\
\hline Bone age (years) & 183 & 12.0 & 10.7 & 13.0 & 11.9 & 1.0 \\
\hline $\begin{array}{l}\text { Prepubertal delta height (Ranke) } \\
\text { (SDS) }\end{array}$ & 540 & 1.5 & 0.8 & 2.5 & 1.6 & 0.7 \\
\hline BMI (SDS) & 536 & 0.4 & -1.0 & 1.7 & 0.4 & 1.1 \\
\hline GH dose (mg/kg wk) & 540 & 0.28 & 0.20 & 0.37 & 0.28 & 0.07 \\
\hline
\end{tabular}

start of GH treatment averaged 9.7 y. Height ( -2.4 SDS) was low in comparison with the normal reference population $(p<$ 0.001 ), but not different (0.0 SDS) in comparison with Turner references. The average projected adult height was $146.1 \mathrm{~cm}$. The initial GH dose, which remained approximately constant up to the end of treatment, averaged $0.27 \mathrm{mg} / \mathrm{kg}$ body weight per week, and was delivered in seven weekly injections in the majority of cases.

After one year of GH treatment, the population had reached a height of -1.9 SDS (Tanner references) or 0.7 SDS (TS references). The median gain in height SDS amounted to 0.5 (Tanner) and 0.7 (TS), respectively. The median height velocity during this particular year was $7.4 \mathrm{~cm}$. As expressed by the studentized residual of 0.0 , the observed height velocity was on the average identical to the height velocity predicted at the start of treatment on the basis of the patients' characteristics (10).

There were 540 patients who fulfilled the criterion regarding the defining age for puberty onset (see Methods) which, on an average, was $13.5 \mathrm{y}$. Height at this age was $141.8 \mathrm{~cm}$, thus corresponding to -1.4 SDS (Tanner) and 1.6 SDS (TS). The overall gain in height, starting from the time GH therapy was introduced, was $21.2 \mathrm{~cm}$ and corresponds to $1.5 \mathrm{SDS}$ (TS). The height gain from the start of puberty to NAH was $9.4 \mathrm{~cm}$, corresponding to -0.5 SDS (Tanner) and 0.0 SDS (TS), respectively.

The average age of patients at NAH was $16.9 \mathrm{y}$, with bone age $(n=148)$ being $14.5 \mathrm{y}$. The median height reached was $151.0 \mathrm{~cm}$ and corresponded to a median gain of $4.9 \mathrm{~cm}$ above the projected height at the time GH therapy started. Median height as expressed in SD scores was -1.9 SDS (Tanner) and 1.5 SDS (TS), respectively.

The relationship between the most frequent karyotypes and some basal characteristics at GH therapy start and at NAH are listed in Table 5. No significant differences were observed between the groups.

Analysis of factors influencing near adult height (NAH) and height gain. Our analysis showed that height $(\mathrm{cm})$ at

Table 4. Characteristics of patients at near final height

\begin{tabular}{|c|c|c|c|c|c|c|}
\hline Variables & $n$ & Median & $10^{\text {th }}$ centile & $90^{\text {th }}$ centile & Mean & $\mathrm{SD}$ \\
\hline \multicolumn{7}{|l|}{ Near final height } \\
\hline Age (years) & 987 & 16.9 & 15.5 & 18.8 & 17.1 & 1.4 \\
\hline Bone age (years) & 148 & 14.5 & 13.5 & 16.0 & 14.7 & 1.2 \\
\hline Height (Tanner) (SDS) & 987 & -1.9 & -3.3 & -0.6 & -1.9 & 1.1 \\
\hline HT-MPH (SDS) & 933 & -2.0 & -3.3 & -0.5 & -2.0 & 1.1 \\
\hline Height TS (Ranke) (SDS) & 987 & 1.5 & 0.1 & 2.9 & 1.5 & 1.1 \\
\hline Pub. delta HT (cm) & 540 & 9.4 & 3.3 & 17.1 & 9.9 & 5.3 \\
\hline Pub. delta HT (Tanner) (SDS) & 540 & -0.5 & -1.1 & 0.3 & 0.4 & 0.7 \\
\hline Pub. delta HT (Ranke) (SDS) & 540 & 0.0 & -0.6 & 0.7 & 0.0 & 0.5 \\
\hline Total delta HT (Tanner) (SDS) & 987 & 0.6 & -0.4 & 1.8 & 0.7 & 0.8 \\
\hline Total delta HT (Ranke) (SDS) & 987 & 1.6 & 0.7 & 2.6 & 1.6 & 0.8 \\
\hline
\end{tabular}


Table 5. Relationship between karyotype and basal characteristics at GH start

\begin{tabular}{|c|c|c|c|c|c|c|}
\hline Karyotype & $n$ & Age at start (yrs) & Height at start $(\mathrm{cm})$ & $\begin{array}{l}\text { Projected Adult } \\
\text { Height }(\mathrm{cm})\end{array}$ & Age NAH (yrs) & Height NAH $(\mathrm{cm})$ \\
\hline $45, X$ & 525 & 9.3 & 117.5 & 146.9 & 16.9 & 151.7 \\
\hline $45, X, \mathrm{iXq}$ & 59 & 10.5 & 119.2 & 144.9 & 17.0 & 149.2 \\
\hline $45, \mathrm{X} / 46, \mathrm{X}, \mathrm{Xr}$ & 34 & 9.8 & 115.6 & 144.4 & 16.7 & 148.5 \\
\hline $45, \mathrm{X} / 46, \mathrm{X}, \mathrm{iXq}$ & 99 & 9.7 & 118.9 & 144.7 & 16.9 & 150.3 \\
\hline $45, \mathrm{X} / 47, \mathrm{XXX}$ & 25 & 10.3 & 121.4 & 146.3 & 16.1 & 152.3 \\
\hline
\end{tabular}

NAH was a function of (in order of importance): 1) height at GH therapy start $(+)$; 2) studentized residual (index of responsiveness) during the $1^{\text {st }}$ year on GH (+); 3$\left.) \mathrm{MPH}(+) ; 4\right)$ age at onset of puberty $(+) ; 5)$ age at GH therapy start $(-)$; and 6) mean dose of GH per week $(+)$. All parameters were significant at a probability level of $p<0.01$.The regression equation is: $\mathrm{NAH}(\mathrm{cm})=142.9+(\mathrm{MPH}[\mathrm{SDS}] \times 1.37)+$ (height at GH start [SDS] $($ TS $) \times 4.11)+$ (studentized residual $1^{\text {st }}$ year $\left.\times 1.99\right)+($ mean $\mathrm{GH}$ dose $[\mathrm{mg} / \mathrm{kg} / \mathrm{wk}] \times$ $4.82)+($ age at puberty start yrs $\times 0.74)$. This equation explains $67 \%$ of the variability of NAH with an error SD of $3.6 \mathrm{~cm}$. The data are listed in Table 6 . The correlations between NAH and its most important determinants are illustrated in Fig. 1.

The gain in height $(\mathrm{cm})$ between GH therapy start and NAH was found to be a function of (in order of importance): 1) age at GH start $(-), 2)$ studentized residual (index of responsiveness) during the $1^{\text {st }}$ year on $\left.\mathrm{GH}(+), 3\right)$ age at puberty start $(+), 4) \mathrm{MPH}(+) ; 5)$ height at GH start $(-), 6)$ mean dose of GH per week $(+)$, and 7) birth weight $(+)$. All parameters were significant at a probability level of $p<0.01$. The regression equation is: delta height $(\mathrm{cm})=64.0+(\mathrm{MPH}$ $[\mathrm{SDS}] \times 1.37)+($ height at GH start $[\mathrm{SDS}](\mathrm{TS}) \times-0.70)+$ (studentized residual $1^{\text {st }}$ year $\times 2.08+($ mean GH dose $[\mathrm{mg} / \mathrm{kg} / \mathrm{wk}] \times 6.73)+($ age at puberty start $[\mathrm{yrs}] \times 0.97)+$ (age at GH start [yrs] $\times-4.76)+($ birth weight $[$ SDS $] \times$ 0.34 ). This equation explains $90 \%$ of the variability of NAH with an error SD of $3.7 \mathrm{~cm}$. The data are listed in Table 6 . The correlations between the total gain in height and its most important determinants are illustrated in Fig. 2.

Table 6. Regression equations for near adult height $(\mathrm{cm})$ and total gain in height $(\mathrm{cm})$

\begin{tabular}{|c|c|c|c|c|}
\hline $\begin{array}{l}\text { Response parameter }(\mathrm{y}) \\
\text { Parameter estimate }(\mathrm{x})\end{array}$ & Rank & $\begin{array}{l}\text { Height } \\
(\mathrm{cm})\end{array}$ & $\begin{array}{l}\text { Height } \\
\text { gain }(\mathrm{cm})\end{array}$ & Rank \\
\hline Intercept & 142.9 & & 64.0 & \\
\hline MPH (SDS) & 1.37 & 3 & 1.37 & 4 \\
\hline Height at GH start (SDS) (TS) & 4.11 & 1 & -0.70 & 5 \\
\hline Studentized residual $1^{\text {st }}$ yr (TS) & 1.99 & 2 & 2.08 & 2 \\
\hline Dose GH (mg/kg/wk) & 4.82 & 6 & 6.73 & 6 \\
\hline Age at puberty start (yrs) & 0.74 & 4 & 0.97 & 3 \\
\hline Age at GH start (yrs) & -0.33 & 5 & -4.76 & 1 \\
\hline Birth weight (SDS) & - & - & 0.34 & 7 \\
\hline$r^{2}$ & 0.67 & & 0.90 & \\
\hline$p<$ & 0.0001 & & 0.001 & \\
\hline Error SD $(\mathrm{cm})$ & 3.6 & & 3.7 & \\
\hline
\end{tabular}

\section{DISCUSSION}

Turner syndrome is a disorder caused by the total or partial loss of one X-chromosome. It occurs with an incidence of about 1:2,000 among females. The main features of TS are short stature $(>90 \%)$, gonadal dysgenesis and a variety of dysmorphic features (1). Short stature is the most consistent symptom, as the extensive studies on spontaneous growth in TS have shown. The patients are short at birth and during childhood and their adult height is about $20 \mathrm{~cm}$ below the population-specific female average (2). The cause of the growth disorder is not fully understood. It is, however, evident that neither a primary disorder in the GH-IGF axis nor the lack of sex steroids plays a major part in the growth disorder; instead, it is haploinsufficiency of the SHOX gene (3) that has been shown to play a crucial role, which, however, has yet to be fully elucidated.

Systematic attempts to promote height in TS began after recombinant human GH became available. In a landmark study, Rosenfeld et al. (19) showed that through long-term treatment with doses higher than the replacement doses applied in treating GH deficiency, height during childhood as well as final adult height could be augmented in TS. In the study, conceived in the early 1980s, age at the start of GH therapy was about $10 \mathrm{y}$ and the overall gain in height over projected adult height $(\mathrm{PAH})$ was about $10 \mathrm{~cm}$. These findings were confirmed in a recent trial which included untreated controls who were observed up to achievement of adult height (20). Similar results were reported from a variety of other studies that were conducted at about the same time $(4,9)$. In addition, various researchers reached the conclusion that $\mathrm{GH}$ treatment in TS was generally safe $(6,7,21)$. In a Cochrane review of articles on final height outcomes, however, it was concluded that the reported gain in height was rather moderate, particularly in view of the high costs involved in longterm treatment (9). More recently it was shown that an even greater gain in adult height could be achieved in Turner patients if higher GH doses were given and treatment was started at an earlier age (5). These observations further strengthen the established fact that the GH dose during the first year of prepubertal treatment is the foremost factor and that it is the responsiveness to $\mathrm{GH}$ which determines height gain during the subsequent prepubertal years (10). Other studies have provided evidence that treatment which is initiated at an earlier age results in a greater gain in height $(22,23)$. Some researchers caution against introducing estrogen re- 

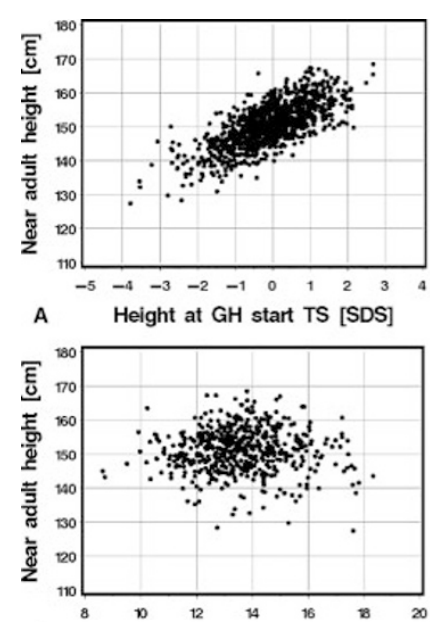

C Age at puberty start [yrs]

Figure 1. Near adult height $(\mathrm{cm})$ in 987 patients with Turner syndrome. Correlation with $(A) \mathrm{HT}$ at GH start, $(B)$ Studentized residual $1^{\text {st }} \mathrm{yr}$ on $\mathrm{GH}$, $(C)$ age at puberty onset, and $(D)$ mean GH dose.
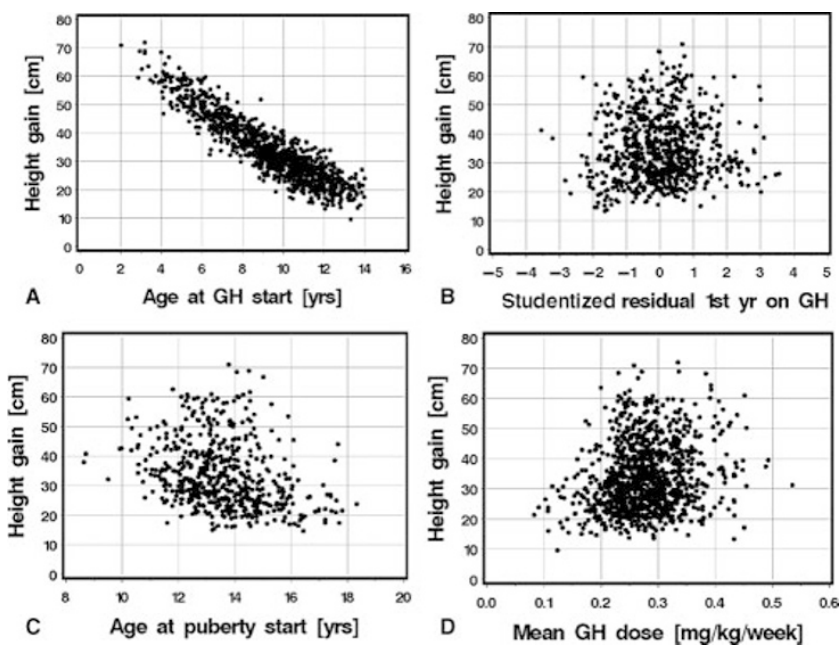

Figure 2. Total gain in height $(\mathrm{cm})$ on $\mathrm{GH}$ in 987 patients with Turner syndrome. Correlation with $(A)$ age at $\mathrm{GH}$ start, $(B)$ Studentized residual $1^{\text {st }}$ yr on $\mathrm{GH},(C)$ age at puberty onset, and $(D)$ mean $\mathrm{GH}$ dose.

placement too early (e.g. $<13$ y of age), as it could possibly interfere with the height outcome $(23,24)$. Medical practice has advanced as a consequence of these findings, and a group of experts has summarized the new therapeutic recommendations in a published report (4).

These world-wide developments are also successively reflected in the treatment of patients enrolled in KIGS. The characteristics of this patient cohort resemble in all respects those observed in other large series initiated in the late 1980s: the GH doses applied were slightly higher than those used in treating GH deficiency, and puberty was generally induced after the age of $13 \mathrm{y}$. The height gain observed was thus comparable with other studies. Our descriptive data show that there is no further gain in relative height after the onset of puberty, a finding which is consistent with our present knowledge concerning the roles of the dose and the response and their relationship with height gain and GH therapy during puberty $(25,26)$. It is important to mention here that only a moderate loss in height occurs during this phase in untreated
TS patients (14). Adult height ( $<18$ yrs of age) was analyzed in a recent study (27) of 704 French Turner patients who were treated between 1986 and 1997 with a mean GH dose of 0.26 $\mathrm{mg} / \mathrm{kg} / \mathrm{wk}$ for $5.0 \mathrm{y}$. GH treatment in these patients started at a mean age of $11.9 \mathrm{y}$ and ended either at a mean age of $14.5 \mathrm{y}$ (due to spontaneous puberty) or at 16.6-17.0 y (after induced puberty). The majority of patients $(n=522)$ received estrogens for the complete induction of puberty at an age of $15.0 \mathrm{y}$. Mean adult height was $14.9 \pm-6.1 \mathrm{~cm}$, i.e. $8.6 \mathrm{~cm}$ above projected height. The French study took a different approach in their multivariate analysis, and their results showed that the most important factors were age at onset and duration of treatment (which are not independent), as these accounted for $66 \%$ of the total $(90 \%)$ explained variability of adult height. The influence of bone age delay, target height, GH dose, frequency of injections, weight, and age at puberty was minor. The detailed analysis of puberty in the French study supports our findings with regard to the slight gain (or no gain) in height after the onset of puberty.

Contrary to our expectations, the height outcomes in our cohort were not affected by the individual karyotypes. This finding is analogous with the situation of spontaneous growth, in which karyotype does not play an important role. Thus, the growth disorder in TS is not associated with the karyotype but, instead, is attributable to the genetic predisposition that TS patients have in common (3). It can also be inferred that the long-term response to GH therapy in TS is related to a factor that is common to all patients. In an earlier study, we showed that the amount of the GH dose as well as the responsiveness to $\mathrm{GH}$ were the main determinants of the height gain during the first prepubertal years in TS (10). In a recent study we demonstrated that both the short-term as well as the long-term gain in height in TS is a function of the polymorphism of the GH receptor gene (27), which was discovered to be a component affecting short-term growth in GH deficiency $(28,29)$. This reinforces and widens the concept that the responsiveness to $\mathrm{GH}$ determines the response, on which several prediction models involving easily accessible auxological parameters were designed (10).

The current analysis was conducted with the aim of determining further factors relevant to the individualization and optimization of GH treatment in young TS patients which could be used to improve the efficacy and the cost-effectiveness of this mode of treatment. The regression equations we derived from a very large cohort of patients indeed support the principal concepts of current treatment in TS; in addition, they offer a means of developing mathematically algorithms which offer a practical tool to calculate both the expected gain in height as well as the expected final height. Our findings show that the parameters which play a role in influencing adult height are the same as those which are involved in the gain in height. Both response parameters are affected by the MPH $(+)$, GH dose $(+)$, responsiveness to $\mathrm{GH}$ $(+)$, age at GH start $(-)$ and age at puberty onset $(+)$. Paradoxically however, absolute height is greater if the patient is tall at GH therapy start, while the gain in height is greater if the patient is relatively short. The magnitude of the explained variability of the outcome variables (67\% and $90 \%$ ) as well as the magnitude of the errors suggest that these regression equations are suitable 
for use as guidelines in daily practice. On the one hand, this means that the GH dose and the timing of puberty onset can be adapted to the individual patient's requirements and responsiveness to GH. On the other hand, this also means that, in certain cases, the GH dose would need to be reduced or that $\mathrm{GH}$ treatment would possibly even be discontinued. The optimal treatment regimen during puberty remains an issue of great practical concern. Clearly, further investigations need to be conducted in which Turner adolescents treated with GH are compared with controls; this modality being ethically justified after appropriate prepubertal treatment is completed.

Acknowledgments. We would like to thank Priscilla Herrmann for her assistance in the preparation of this manuscript.

\section{REFERENCES}

1. Ranke MB, Saenger P 2001 Turner's syndrome. Lancet 358:309-314

2. Ranke MB, Grauer ML 1994 Adult height in Turner syndrome: results of a multinational survey 1993. Horm Res 42:90-94

3. Rao E, Weiss B, Fukami M, Rump A, Niesler B, Mertz A, Muroya K, Binder G, Kirsch S, Winkelmann M, Nordsiek G, Heinrich U, Breuning MH, Ranke MB, Rosenthal A, Ogata T, Rappold GA 1997 Pseudoautosomal deletions encompassing a novel homeobox gene cause growth failure in idiopathic short stature and Turner syndrome. Nat Genet 16:54-63

4. Saenger P, Wikland KA, Conway GS, Davenport M, Gravholt $\mathrm{CH}$, Hintz R, Hovatta O, Hultcrantz M, Landin-Wilhelmsen K, Lin A, Lippe B, Pasquino AM, Ranke MB, Rosenfeld R, Silberbach M 2001 Recommendations for the diagnosis and management of Turner syndrome. J Clin Endocrinol Metab 86:3061-3069

5. van Pareren YK, de Muinck Keizer-Schrama SM, Stijnen T, Sas TC, Jansen M, Otten BJ, Hoorweg-Nijman JJ, Vulsma T, Stokvis-Brantsma WH, Rouwe CW, Reeser HM, Gerver WJ, Gosen JJ, Rongen-Westerlaken C, Drop S 2003 Final height in girls with Turner syndrome after long-term growth hormone treatment in three dosages and low dose estrogens. J Clin Endocrinol Metab 88:1119-1125

6. Growth Hormone Research Society 2001 Critical evaluation of the safety of recombinant human growth hormone administration: Statement from the Growth Hormone Research Society. J Clin Endocrinol Metab 86:1868-1870

7. Quigley CA, Gill AM, Crowe BJ, Robling K, Chipman JJ, Rose SR, Ross JL, Cassorla FG, Wolka AM, Wit JM, Rekers-Mombarg LT, Cutler GB Jr, 2005 Safety of growth hormone treatment in pediatric patients with idiopathic short stature. J Clin Endocrinol Metab 90:5188-5196.

8. Jenkins PJ, Mukherjee A, Shalet SM 2006 Does growth hormone cause cancer? Clin Endocrinol (Oxf) 64:115-121

9. Cave CB, Bryant J, Milne R 2003 Recombinant growth hormone in children and adolescents with Turner syndrome. Cochrane Database Syst Rev 3:CD003887

10. Ranke MB, Lindberg A, Chatelain P, Wilton P, Cutfield W, Albertsson-Wikland K, Price DA 2000 Prediction of long-term response to recombinant human growth hormone in Turner syndrome: development and validation of mathematical models. KIGS International Board. Kabi International Growth Study. J Clin Endocrinol Metab 85:4212-4218
11. Tanner JM, Whitehouse RH, Takaishi M 1966 Standards from birth to maturity for height, weight, height velocity, and weight velocity: British children, 1965. II. Arch Dis Child 41:613-635

12. Ranke MB, Price DA, Albertsson-Wikland KA, Maes M, Lindberg A 1997 Factors determining pubertal growth and final height in growth hormone treatment of idiopathic growth hormone deficiency - Analysis of 195 patients of the Kabi Pharmacia International Growth Study. Horm Res 48:62-71

13. Freeman JV, Cole TJ, Chinn S, Jones PR, White EM, Preece MA 1995 Cross sectional stature and weight reference curves for the UK, 1990. Arch Dis Child $73: 17-24$

14. Ranke MB, Stubbe P, Majewski F, Bierich JR 1988 Spontaneous growth in Turner's syndrome. Acta Paediatr Scand Suppl 343:22-30

15. Lyon AJ, Preece MA, Grant DB 1985 Growth curve for girls with Turner syndrome. Arch Dis Child 60:932-935

16. Niklasson A, Ericson A, Fryer JG, Karlberg J, Lawrence C, Karlberg P 1991 An update of the Swedish reference standards for weight, length and head circumference at birth for given gestational age (1977-1981). Acta Paediatr Scand 80:756-762

17. Ranke MB 1996 Towards a consensus on the definition of idiopathic short stature. Horm Res 45:64-66

18. Greulich WW, Pyle SI. 1952 Radiographic atlas of the skeletal development of the hand and wrist. University Press: Stanford, CA

19. Rosenfeld RG, Attie KM, Frane J, Brasel JA, Burstein S, Cara JF, Chernausek S, Gotlin RW, Kuntze J, Lippe BM, Mahoney CP, Moore WV, Saenger P, Johanson AJ 1998 Growth hormone therapy of Turner's syndrome: beneficial effect on adult height. J Pediatr 132:319-324

20. Stephure DK 2005 Impact of growth hormone supplementation on adult height in Turner syndrome: results of the Canadian randomized controlled trial. J Clin Endocrinol Metab 90:3360-3366

21. Harris M, Hofman PL, Cutfield WS 2004 Growth hormone treatment in children: review of safety and efficacy. Paediatr Drugs 6:93-106

22. Ranke MB, Partsch CJ, Lindberg A, Dorr HG, Bettendorf M, Hauffa BP, Schwarz HP, Mehls O, Sander S, Stahnke N, Steinkamp H, Said E, Sippell W 2002 Adult height after GH therapy in 188 Ullrich-Turner syndrome patients: results of the German IGLU Follow-up Study 2001. Eur J Endocrinol 147:625-633

23. Quigley CA, Crowe BJ, Anglin DG, Chipman JJ 2002 Growth hormone and low dose estrogen in Turner syndrome: results of a United States multi-center trial to near-final height. J Clin Endocrinol Metab 87:2033-2041

24. Chernausek SD, Attie KM, Cara JF, Rosenfeld RG, Frane J 2000 Growth hormone therapy of Turner syndrome: the impact of age of estrogen replacement on final height. Genentech, Inc., Collaborative Study Group. J Clin Endocrinol Metab 85:2439-2445

25. Mauras N, Attie KM, Reiter EO, Saenger P, Baptista J 2000 High dose recombinant human growth hormone $(\mathrm{GH})$ treatment of GH-deficient patients in puberty increases near-final height: a randomized, multicenter trial. Genentech, Inc., Cooperative Study Group. J Clin Endocrinol Metab 85:3653-3660

26. Ranke MB, Lindberg A, Martin DD, Bakker B, Wilton P, Albertsson-Wikland K, Cowell CT, Price DA, Reiter EO 2003 The mathematical model for total pubertal growth in idiopathic growth hormone $(\mathrm{GH})$ deficiency suggests a moderate role of GH dose. J Clin Endocrinol Metab 88:4748-4753

27. Soriano-Guillen L, Coste J, Ecosse E, Léger J, Tauber M, Cabrol S, Nicolino M, Brauner R, Chaussain J-L, Carel J-C 2005 Adult height and pubertal growth in Turner syndrome after treatment with recombinant growth hormone. J Clin Endocrinol Metab 90:5197-5204

28. Binder G, Baur F, Schweizer R, Ranke MB 2006 The d3 growth hormone receptor polymorphism is associated with increased responsiveness to GH in Turner syndrome and short SGA children. J Clin Endocrinol Metab 91:659-664

29. Dos Santos C, Essioux L, Teinturier C, Tauber M, Goffin V, Bougneres P 2004 A common polymorphism of the growth hormone receptor is associated with increased responsiveness to growth hormone. Nat Genet 36:720-724 